\title{
Effects of Plyometric Trainings on Upper Extremity Anaerobic Power and Shotspeed in Male Handball Players
}

\author{
Mahmut Alp (Associate Professor) \\ Suleyman Demirel University, Turkey \\ Mahmut Ozdinc (Research Assistant) \\ Suleyman Demirel University, Turkey
}

Doi:10.19044/ejes.v8no2a60

URL:http://dx.doi.org/10.19044/ejes.v8no2a60

Submitted: 07 April 2021

Accepted: 08 May 2021

Published: 30 June 2021
Copyright 2021 Author(s)

Under Creative Commons BY- NC-ND

4.0 OPEN ACCESS

\begin{abstract}
This paper focuses on the effects of plyometric trainings on upper extremity anaerobic power and shotspeed in 20 volunteer male handball players, who are in the men's handball team at Süleyman Demirel University. Players were randomly divided into two groups as handball training group (HTG) and plyometric training group (PTG). While HTG continued routine handball training, plyometric trainings were applied to PTG additionally for 8 weeks, 3 days a week, at least 30 minutes a day. The upper extremity anaerobic power and shotspeed tests were applied to the groups in $1^{\text {st }}$ and $8^{\text {th }}$ weeks of the period (Inbar et al., 1996). Data analysis was made by using comparison tests. The study reveals that plyometric trainings have positive effects on shotspeed in handball. Considering that plyometric training provides maximum contraction in the shortest time possible, it can be said that applying plyometric training in pre-season and inseason training programming may be more effective.
\end{abstract}

Keywords: Plyometric, anaerobic power, shotspeed, handball

\section{Introduction}

The developments in sport and the increasing performance of athletes has brought about competition. In this developing competitive environment, success is ensured, maintained, and kept at a high level through scientific studies (Başlamışlı \& İri, 2004; Alp et al., 2015; Işıldak, 2020).

Handball is a sport branch that uses anaerobic and aerobic energy systems together, depending on the duration of the fight. It must be sufficiently developed in basic motor characteristics such as strength, velocity, endurance, flexibility, and coordination (Eler \& Bereket, 2001). Through scientific studies, appropriate training methods are planned and applied to develop the basic motoric characteristics required by many sports branches (Ürer, 2014). In addition, anaerobic capacity is one of the main factors which determines the criteria for performance in handball (Suna et al., 2016).

With the developing and changing rules, superior performance expectations from the players has made the game of handball an even faster game. This situation required them to adopt the desired tactics in a shorter period than the time required for jumping, running, changing 
direction, passing, goalshooting, and technical movements in the game (Cardinale, 2001). However, as in every sport, strength is significantly important since the main goal in handball is to gain more goals than the opponent (Gençoğlu, 2008).

To win the game in handball, players' jumping, diving, blocking, passing, ball control, and agility are at the highest level. However, the shooting ability changes the result of the game. The speed of the shot is one of the most important factor for scoring (Van Muijen et al., 1991). In handball, the basic techniques of blocking these shots is to prevent the jumpshot and goal made by the players, and winning the game requires a large amount of jumping strength. The shooting techniques used in handball are largely dependent on the strength of the fingers, wrists, and especially the arm. The most important condition required for the fulfillment of technical and tactical skills in the game is sufficient strength. The rate of shooting in handball varies depending on the ability to generate strength (Komi, 2005).

Plyometric exercise is an effective training when the aim is to improve muscle strength. It is also an important method to increase explosive power to higher levels (James, 1999). Although it is used extensively for the lower extremity, various exercises can also be applied to the upper extremity. In the game of handball, players use both the upper and lower extremities. This include cross runs, jumping, and deception movements with the opponent using the ball or empty runs without the ball for the lower extremities. On the other hand, movements such as block making, various goal throws, 7-meter shooting, holding and pushing the opponent for defense are mostly related to the upper extremity and require strength. Therefore, besides the studies performed to increase the general strength development of the players, the plyometric exercises designed to build upper extremities will have positive effects on both strength development and shooting speed performance (Gençoğlu, 2008; Koçyiğit et al., 2018).

According to the literature on plyometric trainings, Hammami et al. (2019) stated that plyometric training programs allow handball players to improve important components of their physical performance. In addition, Mazurek et al. (2018) emphasized that the plyometric training program of routine handball training improved aerobic capacity and anaerobic fatigue indexes. Also, Chelly et al. (2014) revealed that plyometric training in addition to the standard trainings evolved the features which are important for top performance in handball, particularly examples of explosive strength such as sprints, jumps, and shotspeed. Hermassi et al. (2014) also advised that trainers and conditioners should allocate additional time for plyometric training throughout the season to improve performance in handball players.

Thus, this study focuses on examining the effects of plyometric training on upper extremity anaerobic power and shotspeed in male handball players.

\section{Method}

\section{Participants}

20 handball players competing in the interuniversity 1st league category participated in the study voluntarily. Players were randomly divided into handball training group (HTG) $(\mathrm{n}=$ $10)$ and plyometric training group $(\mathrm{PTG})(\mathrm{n}=10)$. The mean age of the handball players for HTG was $20.60 \pm 1.35$, while PTG was $22.10 \pm 2.13$ years; mean height for HTG was $179 \pm$ 3.94, while PTG was $179.50 \pm 3.83 \mathrm{~cm}$; and the mean weight for HTG was $76.10 \pm 8.64$, while PTG was $78.40 \pm 5.94 \mathrm{~kg}$. 


\section{Measures and Tests}

\section{Measurement of Height}

The height was measured using a measuring tape with an accuracy of $1 \mathrm{~mm}$. The players stood in a flat body position on bare feet during the measurement. Values were recorded in $\mathrm{cm}$ (Alp \& Suna, 2020).

\section{Measurement of Weight}

The weight was measured using a digital scale with a sensitivity of $0.001 \mathrm{~kg}$. The players also dressed lightly during the measurement in order to get accurate data. Values were recorded in $\mathrm{kg}$ (Alp \& Suna, 2020).

\section{Wingate Upper Extremity Anaerobic Strength Test}

Monark $891 \mathrm{E}$ model ergonometer developed for upper extremity anaerobic power measurement was used under standard laboratory conditions. Tests were done at least for two hours after the last meal. Participants were asked not to engage in strenuous physical activities during the rest period and before the tests. However, the tests were explained to each participant before they began each test and the participants had to get acquinted with the test tools. The settings of the ergobike were also made individually for each participant in a way that the athletes were comfortable with their height and the same settings were used in all tests.

A warm-up protocol was applied for 4-5 minutes with two short loads (20-30 W) of 2-3 seconds inbetween, and a warm-up pedal speed of 15-20 rpm without applying any resistance. After the warm up, the athletes rested passively for about 2-3 minutes. Test load was determined as $35 \mathrm{~g}$ per kilogram of body weight for upper extremity in tests performed with ergobyl. The test started after the weight was determined as resistance.Thereafter, the test was placed on the pan of the ergomonark, and the maximum voluntary rotation possible for 30 seconds with loads was requested. Each athlete was verbally encouraged during the test. The pedal speed was also recorded automatically with the help of a photocell connected to the computer (Inbaret al., 1996).

\section{Shotspeed Test}

Ball Coach Pocket Radar was used for the shotspeed test. The shotspeed test was performed in the standard handball court and indoor sports hall. Before the test, each athlete was given 5 minutes to warm up with the ball. While warming up with the ball, the athletes also warmed up with goal throw and passes. After the warm-up, each athlete was asked to shoot as fast as they could to throw the handball into the goal with their own shooting technique. During the shot, one foot of the athlete must touch the ground. They were asked to shoot as fast as they could to the goal, over the seven-meterline. During the shot, the radar was placed $1 \mathrm{~m}$ behind the shooter's shot arm so as not to affect the athlete's shot. It was left blank so that there would be no objects between the radar and the shot arm during the shot. Two shots were given to the athletes and the highest value was recorded as $\mathrm{km} / \mathrm{h}$. At least 15 seconds of rest was given between shots (Zapardiel Cortés et al., 2017).

\section{Procedure}

While the HTG continued with their routine handball training, strength training for the upper extremity was applied to the PTG for 8 weeks, 3 days a week, at least 30 minutes a day in addition to handball training. 


\section{Content of Handball Training}

90 minutes unit trainings were given to the players. The initial stages of the training sessions consist of 20 minutes. This phase consists of the starting run, the handball half-court, general and special warm-up, and opening and stretching. The main phase of the training takes 50-60 minutes. This phase includes mutual and group passing exercises, offensive-defense and fast attack organizations, pivot, playmaker shooting exercises, goalkeeper training, and technique-tactics. The finishing phase of the training takes 10-20 minutes. In this phase, the regional shots, 7-meter shots, and cool-down were terminated.

\section{Content of Plyometric Training}

Bench, $3 \mathrm{~kg}$ medicine balls, and $500 \mathrm{~g}$ health balls were used in the plyometric training. The movements consisted of 2 sets of 15 repetitions in the first 3 weeks, 3 sets of 10 repetitions during the next 5 weeks.

Throwing medicine balls while lying down: Athletes lie on the bench on their back with their arms stretched upwards, the assistant at the head of the table stands with a $3 \mathrm{~kg}$ medicine ball in his hand and drops the ball down. The athlete catches the ball and throws it up again.

Medicine ball sit-up: Athletes lie on the floor in the supine sit-up position. A medicine ball is held on the head and the assistant stands in front of the athelete's auxiliary feet. While the athlete is doing sit-ups, he throws the medicine ball towards the assistant, and while he lies back, the assistant throws the ball back to the athlete.

Throwing medicine ball: The athlete throws a 500g medicine ball to the other assistant in the basic shooting position (Ateş \& Ateşoğlu, 2007).

\section{Statistical Analysis}

Statistical Package Program was used to analyze the data. As a result of the "ShapiroWilk" Normality Test, the data showed a normal distribution. "Descriptive Statistics" and "Paired t-Test" were used to compare the data. Significance level was accepted as "p <.05".

\section{Results}

Table 1. Upper Extremity Results of Groups

\begin{tabular}{lllll}
\hline Group (Watt) & Test Sequence & Mean \pm SD & $\mathrm{t}$ & $\mathrm{p}$ \\
\hline HTG & Pretest & $528.50 \pm 35.99$ & -9.75 & $.000 *$ \\
\cline { 2 - 3 } & Posttest & $536.30 \pm 36.31$ & & \\
\hline PTG & Pretest & $\frac{531.50 \pm 27.49}{544.30 \pm 29.13}$ & -18.39 & $.000^{*}$ \\
\hline
\end{tabular}

Table 1 shows Paired t-Test's results of Upper Extremity. According to Table 1, statistically significant differences were found in both HTG and PTG's upper extremity results $(\mathrm{p}<.05)$.

Table 2. Shot Test Results of Groups

\begin{tabular}{lllll}
\hline Group $(\mathrm{km} / \mathrm{h})$ & Test Sequence & Mean \pm SD & $\mathrm{t}$ & $\mathrm{p}$ \\
\hline HTG & Pretest & $75.20 \pm 3.88$ & -7.66 & .097 \\
\cline { 2 - 3 } & Posttest & $75.50 \pm 3.40$ & & \\
\hline PTG & Pretest & $\frac{73.90 \pm 3.98}{79.00 \pm 3.36}$ & -16.21 & $.000^{*}$ \\
\hline
\end{tabular}


Table 2 shows Paired t-Test's results of Shot Test. According to Table 2, significant difference was found in PTG $(\mathrm{p}<.05)$. However, there was no difference in HTG values $(\mathrm{p}>.05)$. Table 3. Comparison of Groups' Results

\begin{tabular}{lllll}
\hline Test (Watt)Group & Mean \pm SD & $\mathrm{t}$ & $\mathrm{p}$ \\
\hline \multirow{2}{*}{ Pretest } & HTG & $528.50 \pm 35.99$ & \multirow{2}{*}{-.209} & .836 \\
\cline { 2 - 3 } & PTG & $531.50 \pm 27.49$ & & \\
\hline Posttest & HTG & $536.30 \pm 36.31$ & -.543 & .594 \\
\cline { 2 - 3 } & PTG & $544.30 \pm 29.13$ & & \\
\hline
\end{tabular}

Table 3 shows the comparison of the results between the groups. According to Table 3 , there were no differences in both pre and posttest values of the groups $(p>.05)$.

Table 4. Comparison of Groups' Shot Test Results

\begin{tabular}{|c|c|c|c|c|}
\hline \multicolumn{2}{|c|}{ Test $(\mathrm{km} / \mathrm{h})$ Group } & \multirow{2}{*}{$\frac{\text { Mean } \pm \text { SD }}{75.20 \pm 3.88}$} & \multirow{3}{*}{$\frac{\mathrm{t}}{.739}$} & \multirow{3}{*}{$\begin{array}{l}\mathrm{P} \\
.469\end{array}$} \\
\hline Pretest & HTG & & & \\
\hline & $\overline{\mathrm{PTG}}$ & $73.90 \pm 3.98$ & & \\
\hline Posttest & $\begin{array}{l}\text { HTG } \\
\text { PTG }\end{array}$ & $\begin{array}{l}77.50 \pm 3.40 \\
79.00 \pm 3.36\end{array}$ & -.990 & .335 \\
\hline
\end{tabular}

Table 4 shows the comparison of shot test results between groups. Acccording to Table 4 , there were no differences in both pre and posttest values of groups $(\mathrm{p}>.05)$.

\section{Discussion}

The effects of plyometric trainings on upper extremity anaerobic power and shot speed in male handball players were investigated in this study.

Based on the comparison of the upper extremity pre and posttest values of the groups, the difference was statistically significant in both groups $(\mathrm{p}<.05)$. However, no difference was found as a result of the comparison of the pre and posttest values of the groups with each other ( $\mathrm{p}>.05)$. In a similar study conducted on handball players, it was found that 6 weeks plyometric exercises applied to the players' upper extremities did not have positive effects on players' upper extremity muscle strength. It was emphasized that the good training history of the athletes was the reason for the emergence of this result, and it was stated that plyometric training should be applied for a long time in order to improve the upper extremity strength level of handball players (Gençoğlu, 2008). In another study conducted on handball players, strength and resistance training was applied to the players for 8 weeks, and the handball players in the control group continued their current training programs during the same period. Results of the study revealed that when compared with the handball players in the control group, a statistically significant improvement occurred in the upper and lower extremity muscle strength levels of handball players who applied strength and resistance training (Hermassi, 2011).

Furthermore, while comparing the pre and posttest values of the shotspeed of the groups, there was no difference in HTG values ( $p>.05)$ and the difference in PTG values was found significant $(\mathrm{p}<.05)$. No difference was found as a result of the comparison of the pre and post shotspeed test values of the groups with each other $(\mathrm{p}>.05)$.

Earlier on, it was stated that the shot velocity has an important place in the sports branches such as handball where the shooting motion is applied. It is known that especially for the shoulder, internal and external rotator muscles are important determinants on the speed of shooting in 
handball (Marques, 2011). In the study conducted by Pontaga (2014), it was found that the shotspeed of elite handball players was closely related to the strength levels of the athletes. In another study conducted by Marques (2007), it was concluded that maximal dynamic force significantly affects the rate of shot in elite handball players. Hence, it was determined that there was no significant relationship between the shot velocities and the shot hit rates of the handball players participating in the study and in the experimental group after flexi-bar training. On the other hand, in the pre-test parameters of the experimental group, it was determined that the hit rate of the shot had a negative effect on the hit rate of shots fired at some corners of the goal. In the pre-test measurements of control group, no significant relationship was found between the shotspeeds and the shot hit rates. However, in the posttest measurements, it was found that there was a significant relationship between the shot velocities and the shot accuracy rates in general. Therefore, the reason the shot velocity did not affect the shot accuracy positively was the fact that handball players wanted to hit the target in addition to the speed when shooting.

\section{Conclusion}

In conclusion, this study shows that plyometric training positively affects upper extremity anaerobic power and shooting speed in handball players. Considering that plyometric training provides maximum contraction in the shortest time possible, it can be said that applying plyometric training in pre-season and in-season training programming may be more effective. This is because these plyometric training protocols will contribute to future training plans for trainers and athletes in the handball branch. 


\section{References}

Alp, M., Kılınç, F., \& Suna, G. (2015). Hazırlık Sezonunda Hentbolculara Uygulanan Antrenmanların Bazı Antropometrikve Biyomotorik Özellikler Üzerine Etkisinin İncelenmesi. SSTB International Refereed Academic Journal of Sports, Health \& Medical Sciences, 17 Alp, M. \& Suna, G. (2020). Effects of Interval Sprint Trainings on Heart Rate and $50 \mathrm{~m}$ Swimming Performances of Young Male Swimmers. Journal of Education and Learning, 9(2), 242-247 Ateş, M. \& Ateşoğlu, U. (2007). Pliometrik antrenmanın 16-18 yaş grubu erkek futbolcuların üst ve alt ekstremite kuvvet parametreleri üzerine etkisi. Spormetre Beden Eğitimi ve Spor Bilimleri Dergisi, 5(1), 21-28

Başlamışlı, A. \& İri, R. (2004). 18-21 Yaş Arası Erkek Hentbolcularda Çabuk Kuvvet Antrenmanının Motorik ve Antropometrik Özelliklere Etkisi. Türkiye Sosyal Araştırmalar Dergisi, 8: 2-3

Cardinale, M. (2001). Handball Performance: Physiological Considerations and Practical Approach For Training Metabolic Aspects. Materials From 3rd \& 4th Congress Sport Medicine \& Handball From: http://www.sportscoach-sci.com

Chelly, M. S., Hermassi, S., Aouadi, R., \& Shephard, R. J. (2014). Effects of 8-week in-season plyometric training on upper and lower limb performance of elite adolescent handball players. The Journal of Strength \& Conditioning Research, 28(5), 1401-1410

Eler, S. \& Bereket, S. (2001). Türk Ve Yabancı Hentbolcuların Motorik Ve Fizyolojik Parametrelerinin Karşılaştırılması. Gazi Beden Eğitimi Ve Spor Bilimleri Dergisi, 6(4): 46-48 Gençoğlu, C. (2008). Hentbolcularda üst ekstremiteye uygulanan pliyometrik egzersizin atış hızı ve izokinetik kas kuvvetine etkisi (Doctoraldissertation, DEÜ Sağlık Bilimleri Enstitüsü). Hammami, M., Ramirez-Campillo, R., Gaamouri, N., Aloui, G., Shephard, R. J., \& Chelly, M. S. (2019). Effects of a combined upper and lower limb plyometric training program on high intensity actions in female U14 handball players. Pediatric exercise science, 31(4), 465-472 Hermassi, S. C. (2011). Effects Of 8-week in-season upper and lower limb heavy resistance training on the peak power, throwing velocity, and sprint performance of elite male handball players. The Journal of Strength \& Conditioning Research, 25(9), 2424-2433

Hermassi, S., Gabbett, T.J., Ingebrigtsen, J., Van Den Tillaar, R., Chelly, M.S., \& Chamari, K. (2014). Effects of a short-term in-season plyometric training program on repeated sprint ability, leg power and jump performance of elite handball players. International Journal of Sports Science

\& Coaching, 9(5), 1205-1216

Inbar, O., Bar-Or, O., \& Skinner, J.S. (1996). The wingate anaerobic test. Champaign, IL: Human Kinetic

Işıldak, K. (2020). Plyometrik Antrenmanların Çabukluk, Dikey Sıçrama ve Durarak Uzun Atlama Performansı Üzerine Etkisi. Akdeniz Spor Bilimleri Dergisi, 3(1), 36-44 James, C.R. (1999). High Powered Plyometric. Human Kinetics, 1-11

Koçyiğit, B., Çimen, E., \& Karakuş, S. (2018). 12-14 yaş grubu hentbol ve tenis performans sporcuların fiziksel antropometrik ve motorik özelliklerinin karşılaştırılması. Sportif Bakış: Spor ve Ĕ̈itim Bilimleri Dergisi, 5(1), 14-25

Komi, P.V. (2005). Changes in Muscle Activity with İncreasing Running Speed. Journal of Sports Science, 23(10):1101-9

Marques, M.C., Van Den Tillaar, R., Vescovi, J.D., \& González-Badillo, J.J. (2007). Relationship between throwing velocity, muscle power, and bar velocity during benchpress in elite handball players. International journal of sports physiology and performance, 2(4), 414-422

Marques, M.S. (2011). Between Rate Of Force Development Metrics And Throwing Velocity İn Elite Team Handball Players: A Short Research Report. Journal of Human Kinetics,Special Issue, 
53-57

Mazurek, K., Zmijewski, P., Makaruk, H., Mróz, A., Czajkowska, A., Witek, K., \& Lipińska, P. (2018). Effects of short-term plyometric training on physical performance in male handball players. Journal of Human Kinetics, 63, 137

Pontaga, I.V. (2014). Shoulder Rotator Muscle Dynamometry Characteristics: Side Asymmetry and Correlations with Ball-Throwing Speed in Adolescent Handball Players. Journal of Human Kinetics, 42, 41-50

Suna, G., Beyleroğlu, M., \& Hazar, K. (2016). Comparison Of Aerobic, Anaerobic Power Features Basketball and Handball Team Players. Beden Eğitimi ve Spor Bilimleri Dergisi, 10(3), 379-385 Ürer, S.V. (2014). 15- 17 Yaş Grubu Erkek Hentbolculara Uygulanan Üst Ve Alt Ekstremiteye Yönelik Pliometrik Antrenmanların Dikey Sıçrama Performansına Ve Blok Üstü Şut İsabetlilik Oranına Etkisinin Araştırılması. İönü Üniversitesi Beden Eğitimi ve Spor Bilimleri Dergisi, 1(2), 16-38

Van Muijen, A.E., Joris, H., Kemper, H.C., \& Van IngenSchenau, G.J. (1991). Throwing practice with different ball weights: Effects on throwing velocity and muscle strength in female handball players. Research in Sports Medicine: An International Journal, 2(2), 103-113

ZapardielCortés, J.C., FerragutFiol, C., Manchado, C., AbraldesValeiras, J.A., \& VilaSuárez, H. (2017). Difference of the speed of handball throwing during the competition in relation to efficiency: Analysis between the first and these condhalf. 